- (NGOs) hostile to genetic manipulation have produced analyses that conclude the directive should apply because genetic engineering is involved.

Academic scientists and seed and crop companies fear that plants made with the latest gene-editing techniques may share the fate of conventional GM plants in Europe. Strict regulations, cumbersome bureaucracy and activism against GM organisms have meant that scientists in some countries, such as Germany, do not even attempt field trials. The regulations have increased the costs of bringing a GM crop to market, and many European nations do not allow such crops to be cultivated at all. That is frustrating for plant scientists who want their work to be useful to the world, says Jonathan Jones, a plant researcher at the Sainsbury Laboratory in Norwich, UK.

"We hoped that the new plant-breeding techniques would offer ways of achieving the same outcome without the onerous regulations - and fear that might not turn out to be the case," he says.

Many countries outside Europe do not face the same uncertainty, because they regulate GM organisms according to the nature of the product, not how it was made. In the United States, gene-edited crops containing no foreign genetic material are assessed on a case-by-case basis. In 2004, the biotechnology company Cibus, based in San Diego, California, was told that the US Department of Agriculture would not need to regulate its herbicide-resistant oilseed rape, made with an earlier form of gene-editing. Its crop is now cultivated in the United States. (The White House did, however, begin a review of all US biotechnology regulation in July.)

Since 2011, Cibus has asked six countries - Finland, Germany, Ireland, Spain, Sweden and the United Kingdom - whether they would consider its crop to come under the scope of the EU directive. Without guidelines from the commission, each conducted its own analysis and said that it would not. Cibus has now done field trials in the United Kingdom and Sweden, but it put its activities on hold after the commission sent a letter to all EU member states on 15 June, asking them to wait for its legal interpretation.

Whatever the commission decides, it is likely that either a member state, an NGO or a company will sue - meaning that the European Court of Justice may make the final, binding decision on the matter.

Many plant scientists do basic research, so their gene-edited plants never need to leave the greenhouse. But Jansson must plant his cress outside to test its photosynthetic abilities in natural conditions. With his country's approval, he plans to plant the crop in the spring. "Lawyers talk and talk - I think it is important for Europe to have a test case," he Says. - SEE EDITORIAL P.307

\title{
German researchers pledge refugee help
}

\section{Social scientists launch integration studies and warn of need to counter rising xenophobia.}

\section{BY QUIRIN SCHIERMEIER}

A fter civil war broke out in Syria, Mohammad Khamis lost his parents and his home - but not his dream of becoming a scientist. In July 2013, he boarded a flight from Damascus, where he had studied electrical engineering, to Egypt. In Alexandria, he paid traffickers about $€ 5,000$ (US\$5,500) for a boat passage to Europe. The 9-day voyage to the Italian island of Lampedusa, on an unseaworthy sloop with 100 other desperate refugees, was a nightmare of fear, vomit and thirst.

Two years later, Khamis, now 22, is attending classes in maths, physics and chemistry at the Technical University of Munich (TUM) in Germany, where he sought asylum in August 2013 and was last year accepted as a war refugee. "There is no future for me in Syria," he says on a cold December day in Munich. "I would like to stay here to study and find a good research job. My dream is to discover something new."

Social scientists studying the flow of refugees into Germany want to discover something themselves: how many of the incoming people are, like

\section{"Science has a responsibility to help tackle the huge integration challenge ahead."}

Khamis, well-qualified, motivated and eager to learn - a boon for the economy. These migration researchers say that Germany has become a case study in the difficulties of suddenly integrating a large group of culturally diverse foreigners into a society; the nation has registered nearly one million asylum-seekers this year, more than half of them from Syria. It is the highest such influx in Western Europe.

After a short-lived wave of hospitality in September, when chancellor Angela Merkel promised that Germany would be a welcoming host to the persecuted, many citizens and some right-leaning politicians have begun to voice concerns, painting a picture of a Muslimdominated parallel society of poorly trained recipients of social welfare.

Research may be able to counter the rising tide of xenophobia and aid the urgent process of resettling refugees by revealing more about migrants' skills and cultural values, says
David Schiefer, a Berlin-based psychologist with a German advisory body on migration and integration who is planning interviews with refugees. "We need to give these people a voice," he says.

With about half of the newcomers under 25 years of age, Germany's higher-education and science systems have a particular obligation - and the well-funded capacity - to help, say researchers. "Science has a responsibility to help tackle the huge integration challenge ahead," says Alexander Kurz, head of human resources at the Fraunhofer Society in Munich, which runs centres for applied research. "There is great readiness among our staff of 25,000 scientists from 100 nations to provide mentorship and practical help."

\section{LISTENING TO REFUGEES}

Reliable data on refugees' qualifications and backgrounds are lacking. "We're poking around in the fog," says Ludger Wößmann, a director of the Ifo Center for the Economics of Education in Munich. International assessments of 15-year-olds suggest that up to twothirds of Syrian refugee students might lack basic reading, writing and maths skills, he says. German industrial groups say that the large majority of migrants have minimal skills and poor language abilities, making them hardly employable.

But these assumptions are ill-informed, says Steven Vertovec, director of the Max Planck Institute for the Study of Religious and Ethnic Diversity in Göttingen. In fact, the newcomers are probably as diverse as German society at large, he says. "There are many highly educated, secularized people among the Syrians, Iraqis and Afghans who are seeking asylum here."

Vertovec is leading a study in Lower Saxony in northern Germany that aims to interview asylum-seekers to examine their needs and aspirations, as well as to uncover best practices for responding to refugees. The goal is to produce practical guidelines for city workers and volunteer social workers in asylum-seeker camps on how to work with groups of migrants who may differ enormously in age, religion, language and education status. "Successful integration requires a nuanced understanding of migrants' backgrounds and values," he says. 
Students such as Khamis (who officially has 'guest' status at TUM; he is not yet formally enrolled in Germany's university system) are not an uncommon sight in the country's university lecture halls. TUM has about 100 guest students; across the country, there are a few thousand. To help universities to cope with the influx, the government in November approved an extra $€ 100$ million for student counselling, language training and stipends.

\section{GOVERNMENT SUPPORT}

On 11 December, Germany's main researchfunding agency, the DFG, encouraged grant holders to consider hiring refugee scientists in their research. DFG-funded scientists whose work would benefit from the participation of qualified academics or $\mathrm{PhD}$ students among the refugees are free to submit supplemental proposals for 'guest funding', said DFG president Peter Strohschneider.

In a strategy paper seen by Nature, a group from seven Max Planck institutes, in response to a call for research ideas by the society's president, Martin Stratmann, has outlined a variety of research needs around humanitarian migration, from international law and human-rights issues to health and gender studies.

Marie-Claire Foblets, director of the Max Planck Institute for Social Anthropology in Halle, plans to ask a culturally diverse group

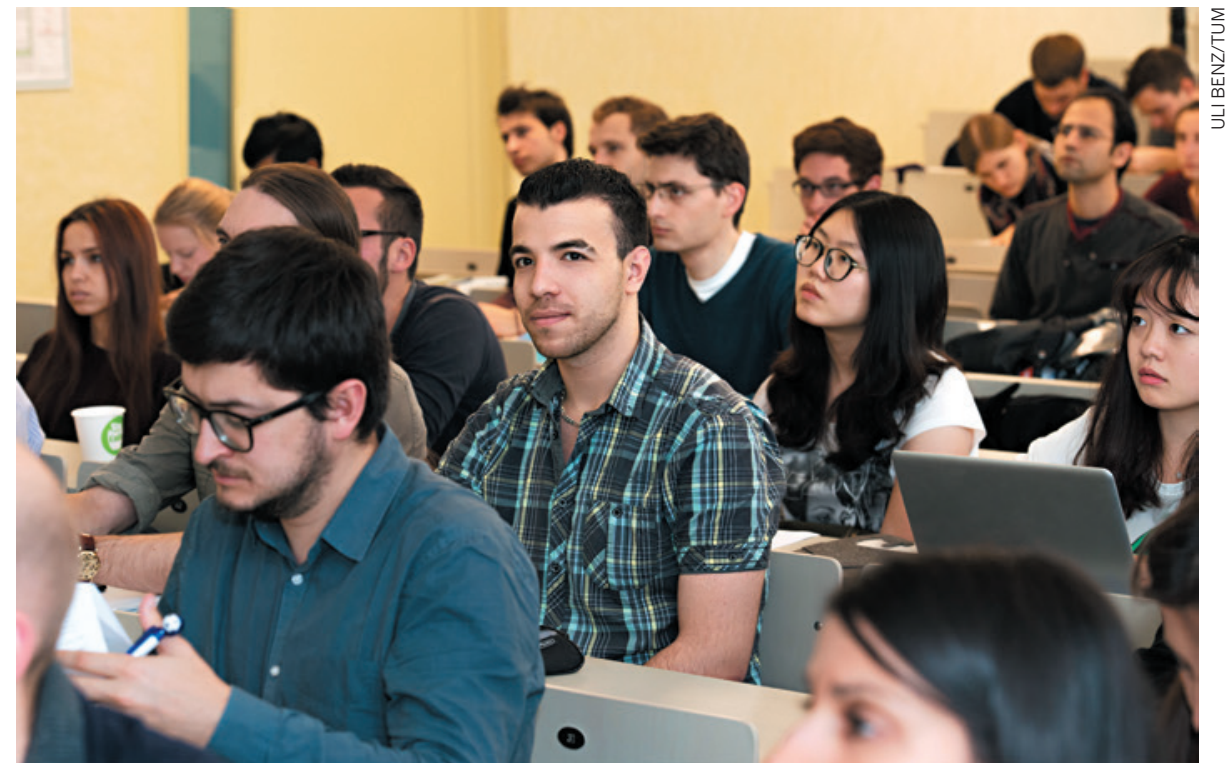

Mohammad Khamis (centre), who left Syria in 2013, is now attending the Technical University of Munich.

of refugees - including guest students at the University of Halle-Wittenberg — for accounts of their lives and experiences. Other questions, such as those concerning refugees' citizenship and civil rights, the potential lure of extremism, and the fate of children who might be staying with radicalized parents, will require the involvement of law experts, criminologists, educators and others, she says.

Khamis, for one, is happy to write up the story of his life for research. Having passed German-language tests, he hopes to enrol at the university next term as a regular student. "Germany has been good to me," he says. "Now that my life can start again I do hope that I can give something back." - SEE EDITORIAL P.308 